\title{
Vitamin C and infectious diseases
}

\section{Hemilä, Harri}

Springer-Verlag

1998

Hemilä , H 1998 , Vitamin C and infectious diseases . in R Paoletti , H Sies , J Bug , E Grossi \& A Poli (eds), Vitamin C: the state of the art in disease prevention sixty years after the Nobel Prize. Springer-Verlag, Milano, pp. 73-85 .

http://hdl.handle.net/10138/228069

publishedVersion

Downloaded from Helda, University of Helsinki institutional repository.

This is an electronic reprint of the original article.

This reprint may differ from the original in pagination and typographic detail.

Please cite the original version. 


\title{
Vitamin C and Infectious Diseases
}

\author{
H. HEMILÄ
}

\section{Introduction}

Early in this century several authors suggested that vitamin $\mathrm{C}$ intake may have beneficial effects on the incidence and severity of various infections. Two exhaustive bibliographical searches of the old literature on vitamin $\mathrm{C}$ and infections have been published. One of them was overenthusiastic [1] in its interpretation of the findings, whereas the other was overly pessimistic [2]; neither offered any statistical analysis of the available data. However, a quantitative analysis of controlled studies has been published recently [3]. The mechanisms whereby vitamin $\mathrm{C}$ affects the immune system are poorly understood, although there are reports indicating that it affects the functions of phagocytes, the proliferation of $\mathrm{T}$ lymphocytes, the production of interferon, and the replication of viruses [3-5].

\section{Infections in Animals}

Most mammals synthesize vitamin $C$ in their liver [6]. The guinea pig is one of the rare species that has lost this capability and thus provides a good experimental model for studies examining its effects. Vitamin C intake affects the susceptibility of guinea pigs to infections by bacteria and other microorganisms [3,7-31].

Primates also lack the ability to synthesize vitamin C [6]. Albert Sabin found that many rhesus monkeys on a vitamin C-deficient diet succumbed to spontaneous infections, chiefly pneumonia and enterocolitis, while those administered vitamin $\mathrm{C}$ remained well [32]. In marmosets, vitamin $\mathrm{C}$ supplementation decreased morbidity and mortality due to parainfluenza infection [33].

Mice, rats, and rabbits synthesize vitamin $\mathrm{C}$ in their livers and thus cannot be used to study the effects of vitamin $\mathrm{C}$ deficiency, but the effects of supple- 
mentation can be studied in these species. Vitamin C decreased the morbidity and mortality of animals infected with several different kinds of microorganisms [3, 34-38]. Furthermore, it has been commented that humans, monkeys, and the guinea pig are susceptible to both the human and bovine tubercle bacillus, whereas mice, rats and dogs, which synthesize vitamin $\mathrm{C}$, are resistant to them [39].

\section{Infections in Humans}

\section{The Common Cold}

The effect of vitamin $\mathrm{C}$ on the common cold has been extensively studied, primarily because of the wide publicity provoked in the early 1970s by Linus Pauling [40, 41]. Pauling did not carry out any experimental work himself, but based his conclusions on published data. So far, over 60 interventional studies examining this issue have been published [42], The effect of vitamin $C$ on the common cold has been a controversial issue largely because of conflicting results. Nevertheless, important consistencies in the results can be seen on careful analysis.

\section{Incidence of the Common Cold}

There is strong evidence that large-dose vitamin $\mathrm{C}$ supplementation has no effect on the number of common cold episodes in ordinary people in Western countries. None of the six largest trials found any significant effect, and when their results were combined, no difference was seen between vitamin $\mathrm{C}$ and placebo groups [43], In these trials there were over 3500 subjects and over 5000 common cold episodes in all.

Nevertheless, a number of small-scale trials have found a significantly lower number of colds in a group supplemented with vitamin $C$ and it is possible that some of these positive results are explained by the use of different kinds of subjects or by other differences in experimental conditions when compared to the six largest trials.

It was suggested that subjects under acute heavy physical stress forms one group in which vitamin $\mathrm{C}$ supplementation may be beneficial. In three placebocontrolled trials, the number of cold episodes was decreased on average by $50 \%$ in the vitamin $\mathrm{C}$ groups [44]. In a fourth study, vitamin $\mathrm{C}$ also decreased common cold incidence significantly but the control group was not administered a placebo [45].

Furthermore, it is possible that some of the positive results on cold incidence are not due to the high vitamin $\mathrm{C}$ dose per se, but rather to the correction of marginal deficiency. In the UK, the dietary vitamin C intake is particularly low among the Western countries, and in four trials in British men vitamin $\mathrm{C}$ decreased the incidence of the common cold on average by $30 \%$ [43]. One of the 
UK trials used a low vitamin $\mathrm{C}$ dose, $80 \mathrm{mg} / \mathrm{day}$, implying that the benefit was due to correcting marginal deficiency $[43,46]$,

Some further studies have also observed preventive benefits from vitamin C on common cold incidence [40, 41, 47]. Nevertheless, the six largest trials show that subpopulations in Western countries potentially benefiting from regular vitamin $\mathrm{C}$ supplementation are rather restricted [43],

\section{Severity of Common Cold Episodes}

Placebo-controlled trials have shown that vitamin $\mathrm{C}$ alleviates the symptoms and shortens the duration of the common cold. However, there has been great divergence in the results, some studies reporting only a $5 \%$ decrease, while a few have reported an up to $50 \%$ decrease in the duration or severity of colds among the vitamin $\mathrm{C}$ group [47-51].

There is some evidence of variation in the size of the benefit between subgroups. Vitamin $\mathrm{C}$ may be more beneficial in subjects with a low dietary intake of the vitamin and in adults in regular contact with children [3]. Studies in children also tend to reveal greater benefit than studies in adults and studies using larger doses tend to reveal greater benefit [51]. Karlowski et al. [52] found that 6 $\mathrm{g} /$ day produced approximately twice as great a benefit as $3 \mathrm{~g} /$ day, implying dose dependency in the $>1 \mathrm{~g} /$ day region $[51,53]$.

Essentially all published trials have examined the effect of regular vitamin $\mathrm{C}$ supplementation. However, if the goal is to alleviate the symptoms of cold episodes, it appears more rational to administer vitamin $\mathrm{C}$ therapeutically, starting immediately after the first symptoms, but few such trials have been carried out $[48,51]$. Promptness may be important in such therapeutic supplementation. Asfora [54] found great benefit from vitamin C (6 g/day for 5 days) when treatment was initiated within $24 \mathrm{~h}$ of the onset of common cold symptoms. The benefit was considerably less when initiated $24-48 \mathrm{~h}$ after onset, and no benefit was seen with still later initiation of treatment.

\section{Pneumonia}

In one of his last texts Albert Szent-Györgyi mentions a personal experience [55]: "Last year I collected a rather unfortunate personal experience. I broke down with pneumonia which I could not shake off for months, until I discovered that the quantities of ascorbic acid which I took (one gram daily) had become insufficient at my age ( 84 years). When I went up from one gram to eight, my troubles were over."

There are numerous other suggestions that vitamin $\mathrm{C}$ may have therapeutic benefits in pneumonia patients [56-65]. However, we are aware of only one randomized trial pertinent to this issue [66], carried out in the UK with elderly hospital patients with pneumonia $(n=17)$ and acute bronchitis $(n=40)$. Therapeutic vitamin $\mathrm{C}(0.2 \mathrm{~g} /$ day $)$ caused a statistically significant decrease in a score of respiratory symptoms in those patients who were most severely ill when admitted to 
hospital, and a decrease bordering on statistical significance in all patients. Furthermore, there were six deaths among the patients, all due to respiratory infection; five in the placebo group, but only one in the vitamin $C$ group [66].

Vitamin $\mathrm{C}$ intake can also have preventive effects on pneumonia. Three studies have reported the number of pneumonia cases in vitamin $\mathrm{C}$ and control groups [67-69], each of these studies finding at least an $80 \%$ lower incidence of pneumonia in the vitamin $\mathrm{C}$ group and the difference being statistically significant in each case [70]. The latest of these studies was a double-blind, placebocontrolled trial with marine recruits in the USA [69]. In contrast, placebo was not used in the two older studies $[67,68]$. Dietary vitamin C intake was low in the older studies $[67,68]$ and the benefit of higher vitamin $C$ intake may be explained by the correction of marginal deficiency. However, in the latest trial [69] dietary intake was rather high, and the effect thus seems to be due to the large dose per se ( $2 \mathrm{~g} /$ day). In this respect, these studies do not yield a simple biological explanation of the observed benefits.

\section{Other Infections}

There is limited and fragmentary data on the possible effects of vitamin $\mathrm{C}$ on other infections, yet the available data strongly suggest that the effects are not restricted to the common cold and pneumonia [1-39, 71]. Findings of three particularly interesting trials are shown in Table 1.

Glazebrook and Thomson [67] studied schoolboys in an institution in the UK. A placebo was not used, but vitamin $\mathrm{C}$ was added to food in the kitchen and it is unlikely that a placebo effect would have occurred in the dining hall. No difference was seen in tonsillitis incidence between the study groups. However, prominent differences between the control and vitamin $\mathrm{C}$ groups were seen among the subjects who contracted tonsillitis. In the vitamin group fewer tonsillitis patients were referred to hospital and their average stay at the hospital was shorter (Table 1). A further interesting finding in this trial was the absence of pneumonia and rheumatic fever in the vitamin group. This trial shows that vitamin $\mathrm{C}$ may have quite variable effects on different infectious disease endpoints. It is similarly noteworthy that Pitt and Costrini [69] found no effect on common cold incidence but an $85 \%$ decrease in pneumonia incidence in the vitamin $C$ group $[43,70]$. Glazebrook and Thomson estimated that the dietary vitamin $C$ intake of schoolboys was only $10-15 \mathrm{mg} /$ day [67]. It is thus possible that the observed benefits are due to the correction of marginal deficiency. Consequently, even if we assume that their results reflect genuine biological effects, great care must be exercised when extrapolating such findings to other population groups.

Ritzel [72, 73] carried out a double-blind, placebo-controlled trial with schoolchildren in a skiing camp in Switzerland, which belongs to the group of studies with subjects under acute heavy physical stress [44]. He observed a substantial decrease in the number of pharyngitis, laryngitis, and tonsillitis episodes, and in the number of bronchitis episodes in the vitamin $\mathrm{C}$ group 
(Table 1). The trial was small and these decreases were not significant statistically, but they are consistent with the observed effect on common cold incidence. A substantial difference between the groups in the occurrence of other symptoms was also reported (Table 1).

Table 1. Vitamin $\mathrm{C}$ and infectious diseases

\begin{tabular}{|c|c|c|c|c|c|}
\hline \multirow{2}{*}{$\begin{array}{l}\text { Study } \\
\text { (vitamin C dose) }\end{array}$} & \multirow[b]{2}{*}{ Number } & \multicolumn{2}{|c|}{ Study group } & \multirow[b]{2}{*}{ Decrease } & \multirow{2}{*}{$\begin{array}{l}p \text { Value }^{\mathrm{a}} \\
\text { (one-tail) }\end{array}$} \\
\hline & & Vitamin C & Control & & \\
\hline \multirow{7}{*}{$\begin{array}{r}\text { Glazebrook and Thomson } \\
1942 \text { [67] }(0.05-0.3 \text { g/day })\end{array}$} & Subjects & 335 & 1100 & & \\
\hline & Common cold & 72 & 286 & $17 \%$ & 0.047 \\
\hline & Tonsillitis & 29 & 94 & $0 \%$ & 0.5 \\
\hline & Admitted to hospital & 18 & 83 & $30 \%$ & 0.002 \\
\hline & Days in hospital & 10.1 & 16.7 & $40 \%$ & 0.013 \\
\hline & Pneumonia & 0 & 17 & $100 \%$ & 0.005 \\
\hline & Rheumatic fever & 0 & 16 & $100 \%$ & 0.007 \\
\hline \multirow{6}{*}{$\begin{array}{l}\text { Ritzel } 1961[41,72,73] \\
\text { (1 g/day) }\end{array}$} & Subjects & 139 & 140 & & \\
\hline & Common cold & 17 & 31 & $45 \%$ & 0.015 \\
\hline & $\begin{array}{l}\text { Pharyngitis, laryngitis } \\
\text { and tonsillitis }\end{array}$ & is & 14 & $50 \%$ & 0.062 \\
\hline & Bronchitis & 8 & 13 & $38 \%$ & 0.14 \\
\hline & Other symptoms $s^{b}$ & 8 & 21 & $62 \%$ & $-b$ \\
\hline & Total days of illness ${ }^{c}$ & 9 & 48 & $81 \%$ & \\
\hline \multirow{4}{*}{$\begin{array}{l}\text { Terezhalmy et al. } 1978 \text { [74] } \\
(0.6 \text { g/day) }\end{array}$} & Subjects & 19 & 10 & & \\
\hline & Herpes labialis & & & & \\
\hline & Days of pain & 1.7 & 3.5 & $51 \%$ & $<0.001$ \\
\hline & Days before healing & 4.2 & 9.7 & $57 \%$ & $<0.001$ \\
\hline \multirow[t]{2}{*}{$(0.6-1.0 \mathrm{~g} /$ day $)$} & Subjects & 38 & 10 & & \\
\hline & $\begin{array}{l}\text { Herpes labialis } \\
\text { Patients with } \\
\text { vesicle formation }\end{array}$ & 14 & 10 & $63 \%$ & $<0.001$ \\
\hline
\end{tabular}

${ }^{a}$ With continuous data, $p$ value was calculated using the $t$-test, and with dichotomous data the mid- $p$ value was calculated [3].

b Muscle ache, headache, abdominal pain, vomiting, diarrhea, general malaise. $p$ Value not calculated since the outcome is highly heterogeneous.

c Days of illness per group for other symptoms. 
Terezhalmy et al. [74] carried out a double-blind, placebo-controlled trial with subjects with recurrent herpes labialis. The duration of pain and the percentage of subjects with vesicle formation were both significantly reduced by vitamin $\mathrm{C}$ (Table 1). No meaningful difference was seen between 0.6 and 1.0 $\mathrm{g} /$ day doses, suggesting that saturation was reached at $0.6 \mathrm{~g} /$ day or lower. A further interesting finding in this trial was that prompt initiation of treatment within $24 \mathrm{~h}$ was more beneficial than later initiation [3,74], consistent with Asfora's findings with the common cold [54]. Bioflavonoids were given along with vitamin $\mathrm{C}$ and it is unknown to what extent they are responsible for the differences between the study groups.

A number of authors have suggested that vitamin $\mathrm{C}$ may be beneficial in patients with tuberculosis $[1,3,75-84]$ and for preventing and treating viral hepatitis [1, 3, 64, 65, 71, 85-91], With all the evidence indicating that vitamin C has nonspecific effects on the immune system and on various infections [3-39], it seems clear that these old reports should not be disregarded without further carefully designed trials. Vitamin $\mathrm{C}$ has been suggested as having beneficial effects on still further infections, but they are not commented on here [1-3, 7 , $64,65,92-98]$.

\section{Problems in Interpreting the Vitamin C Studies}

Szent-Gyorgyi stated that "as to ascorbic acid, right from the beginning I felt that the medical profession misled the public. If you don't take ascorbic acid with your food you get scurvy, so the medical profession said that if you don't get scurvy you are all right. I think that this is a very grave error. Scurvy is not the first sign of the deficiency but a premortal syndrome, and for full health you need much more [71,99]."

This oversimplified view vividly described by Szent-Györgyi in separate instances [1,100-103] is still prevalent. It recently was shown that three highly influential reviews [104-106] concluding that vitamin $\mathrm{C}$ is not efficacious against the common cold misrepresented data from the original publications and analyzed the data improperly [107, 108]. Furthermore, the authors of the most influential common cold trial, which was carried out at the National Institutes of Health in the USA [52], concluded that the apparent benefit from vitamin $\mathrm{C}$ was actually caused by the placebo effect. However, the placebo effect was recently shown to be an erroneous explanation of these findings [53]. It is noteworthy that two of these biased papers $[52,104,109]$ were authored by Thomas Chalmers who was a highly influential pioneer of randomized trials [110]. It seems that the biased analysis of data in the four important papers [52, 104-106] is largely explained by uncritical adherence to the concept that the physiological purpose of vitamin $C$ is merely to prevent scurvy $[3,108,111]$.

There are many more problems in interpreting the vitamin $\mathrm{C}$ studies $[3$, 108]. A particular difficulty arises from the fundamental difference between vitamin $\mathrm{C}$ and ordinary drugs such as antibiotics. It is possible to select a control 
group which has no intake of an ordinary drug, making the interpretation of results reasonably simple. It is impossible, however, to select control subjects who have no vitamin $\mathrm{C}$ intake and no vitamin $\mathrm{C}$ in their body. Consequently, all intervention studies with vitamin $\mathrm{C}$ compare two different intake levels. The lower level arising from diet has not usually been estimated at all, making the comparison between studies and the generalization of findings problematic issues.

One important problem that has hampered acceptance of the notion that vitamin $\mathrm{C}$ supplementation can produce benefits is concern for safety. For example, in a recent review Victor Herbert [112] stated that vitamin C may lower plasma vitamin 612 levels and reduce insulin production. However, speculation that vitamin $C$ breaks down vitamin 612 was shown to be false over two decades ago [71, 113-115], and speculation that vitamin $C$ reduces insulin production was based on a single study from the year 1946 with alloxan treated rats; however, the original authors explicitly stated that vitamin $\mathrm{C}$ alone had no effect on their rats [115]. The safety of vitamin $C$ is of no real concern $[65,71$, 100,115-117]. In his reminiscences Pauling [118] recalled that the reason he sat down and wrote the bestselling book reviewing the evidence that vitamin $C$ is beneficial against the common cold [40] was an acrimonious exchange of letters with Herbert who authored the biased review claiming that vitamin $\mathrm{C}$ is harmful $[112,115]$.

Some people such as Szent-Györgyi [1, 55, 99-103], Pauling [40, 41, 71, 99], and Stone [ 1 ] were able to see that the physiological role of vitamin $C$ is not limited to the prevention of scurvy. Nevertheless, they were overly enthusiastic when extrapolating the reported benefits of higher doses to the general population in Western countries $[3,43,47,51]$. For example, they did not properly consider the possibility that the reported benefits of high doses were due to the correction of marginal deficiency, in which case their conclusions from the published findings would probably have been more moderate.

\section{The Need for Further Trials}

Paul Knipschild [119] describes how a colleague once asked him to help set up a preventive trial on vitamin $\mathrm{C}$ and the common cold. However, before undertaking a new trial he decided first to carry out a systematic review of the issue to see what was previously known and this led to a thorough and useful bibliography on the subject [42].

Judging by published reports, many other workers did not take a proper look at the literature to formulate relevant questions for their own trials. Consequently, many published trials teach us little, if anything. For example, in 1975 it was reported that $6 \mathrm{~g} /$ day of vitamin $\mathrm{C}$ caused twice as great a benefit as $3 \mathrm{~g} / \mathrm{day}$, and therapeutic supplementation was found to be more efficacious than regular supplementation [51-53]. Nevertheless, after 1975 only one paper has reported a therapeutic trial administering $6 \mathrm{~g} /$ day [54]. Strangely enough, in this double-blind, placebo-controlled trial patients receiving vitamin $\mathrm{C}$ could be 
identified by their clinical progress, which led to the breakdown of blindness in the trial [54], Since 1975 several trials have examined the effect of a regular 1 g/day dose [48-51], which seems largely a waste of time and resources considering the data published before those trials.

According to the available evidence, there is no sound reason to research the effects of regular vitamin $C$ supplementation on the incidence of infections in Western countries, except in carefully selected population groups. Regular supplementation trials are recommended in populations with low vitamin $C$ intakes combined with a particular problem with infections. Such conditions are common in the developing countries.

Therapeutic trials on various infections are encouraged, irrespective of the nutritional background of the patients, although the greatest benefits may be anticipated with patients initially having an unsatisfactory diet. Different doses and different supplementation protocols should be compared in such trials. In planning such therapeutic trials, the reports by physicians who have been using vitamin $\mathrm{C}$ in their clinical practice may provide useful information on appropriate doses and on the possible ways of administering the vitamin.

\section{Conclusions}

In the first part of this century numerous reports were published, concluding that vitamin C has effects on various infections. Szent-Györgyi himself believed at the end of the 1930s that "vitamins, if properly understood and applied, will help us reduce human suffering to an extent which the most fantastic mind would fail to imagine [99]." In those days Szent-Györgyi was shocked by the lack of biological insight and by the lack of interest in the basic problems on the part of the leading clinicians [103].

The role of vitamin $\mathrm{C}$ in preventing and treating infections was not dismissed because of large-scale controlled trials showing that the vitamin is ineffective. There seem to be two particular reasons why the early reports were disregarded. Antibiotics were introduced in the middle of this century. They have specific effects on bacteria and are therefore much more rational drugs for patients with specified infections than vitamin $C$. The second reason seems to be the strong adherence to the notion that vitamin $\mathrm{C}$ is just for preventing scurvy. Evidently it was unreasonable to consider that a substance participating in collagen synthesis might have effects on infections. However, the biochemistry of vitamin $\mathrm{C}$ is complex and not at all limited to collagen metabolism. Numerous reports have shown that vitamin $C$ has effects on the immune system [3-5]. Vitamin $\mathrm{C}$ is not a specific agent against any particular infection but possibly has moderate effects on general resistance to infections. Much more work is needed to discover the practical importance of vitamin $\mathrm{C}$ in preventing and treating infections. 


\section{References}

1. Stone I (1972) The healing factor: vitamin C against disease. Grosset and Dunlap, New York

2. Briggs M (1984) Vitamin C and infectious disease. In: Briggs MH (ed) Recent vitamin research. CRC Press, Boca Raton, pp 39-81

3. Hemilä H (1997) Vitamin C and infectious diseases. In: Packer L, Fuchs J (eds) Vitamin C in health and disease. Dekker, New York, pp 471-503

4. Cunningham-Rundles WF, Berner Y, Cunningham-Rundles S (1993) Interaction of vitamin $C$ in lymphocyte activation: current status and possible mechanisms of action. In: Cunningham-Rundles $S$ (ed) Nutrient modulation of the immune response. Dekker, New York, pp 91-103

5. Jariwalla RJ, Harakeh S (1996) Antiviral and immunomodulatory activities of ascorbic acid. Subcell Biochem 25:215-231

6. Nishikimi M, Yagi K (1996) Biochemistry and molecular biology of ascorbic acid biosynthesis. Subcell Biochem 25:17-39

7. Perla D, Marmorston J (1937) Role of vitamin C in resistance. Arch Pathol 23:543575;683-712

8. Leichtentritt B (1924) Der Ablauf der Tuberkulose des Meerschweinchens bei Darreichung von akzessorischen Närhstoffen. Dtsch Med Wochenschr 50:672-673

9. Nassau E, Scherzer M (1924) Skorbut und Infekt beim Meerschweinchen. Klin Wochenschr 3:314-316

10. Heymann B (1926) Versuche an Meerschweinchen über die Beziehungen zwischen Skorbut und chronischer Tuberkulose. Klin Wochenschr 5:59-62

11. Bieling R (1927) Unterernährung und Infektion. Dtsch Med Wochenschr 53:182-183

12. Borghi B (1933) Trypanosomiasi ed avitaminosi. Atti Accad Lincei 17:665-671

13. Basu NK (1934) Tuberculosis and deficiency of vitamins. Int J Vitam Nutr Res 3:91-93

14. Euler H, Malmberg M (1934) Ein Anti-Pneumonie-Faktor in C-Vitamin-haltigen Früchten. Naturwissenschaften 22:205

15. Rinehart JF (1935) Studies relating vitamin C deficiency to rheumatic fever and rheumatoid arthritis: rheumatic fever. Ann Intern Med 9:586-599

16. Schultz MP (1936) Cardiovascular and arthritic lesions in guinea-pigs with chronic scurvy and hemolytic streptococcic infections. Arch Pathol 21:472-495

17. Scoz G, Cattaneo C (1936) Hypovitaminosis C and experimental tuberculosis. Boll Soc Ital Biol Sper 11:909-911

18. Taylor S (1937) Scurvy and carditis. Lancet 1:973-979

19. Montalti M, Passerini P (1938) Influenza dell' acido ascorbico sulla produzione sperimentale di agglutinine antitifiche. Boll Ist Sieroterap Milan 17:495-503

20. Ardy C (1939) Vitamina C e potere opsonico del sangue. Pathologica 31:384-388

21. Pecorella F (1940) Vitamina C ed anticorpi agglutinati. Boll Ist Sieroterap Milan 19:9-14

22. Jusatz HJ (1939) Ueber den Einfluss von Vitamin C auf Immunitätsvorgange. Int J Vitam Nutr Res 9:75-95

23. Vasile B (1940) Influenza della vitamina C in forti dosi nella infezione sperimentale da bacterium coli. Boll 1st Sieroterap Milan 19:44-47

24. Kleimenhagen P (1941) Üeber den Einfluss von Vitamin C auf tuberkulos infizierte Meerschweinchen. Int J Vitam Nutr Res 11:209-227

25. Jones CM, Bartlett MK, Ryan AE, Drummey GD (1943) The effect of sulfanilamide powder on the healing of sterile and infected wounds. N Engl J Med 229:642-646

26. Meyer E, Meyer MB (1944) The pathology of Staphylococcus abscesses in vitamin C-deficent guinea pigs. Bull Johns Hopkins Hosp 74:98-117 
27. Nigro T (1945) Complesso vitaminico C e difesa umorale. Pathologica 37:29-34

28. Barilli L, Paradise M, Moggi P (1952) L'azione della vitamina C sul Mycobacterium tuberculosis. Riv Clin Pediatr 50:334-338

29. Bank S (1975) Prevention of rabies by vitamin C. Nature 258:153-154

30. Bank S (1977) Prophylactic effect of vitamin C on the incidence of rabies in guinea pigs inoculated with fixed rabies virus. Int J Vitam Nutr Res [Suppl 16]:235-244

31. Goldschmidt MC, Masin WJ, Brown LR, Wyde PR (1988) The effect of ascorbic acid deficiency on leukocyte phagocytosis and killing of Actinomyces viscosus. Int $\mathbf{J}$ Vitam Nutr Res 58:326-334

32. Sabin AB (1939) Vitamin C in relation to experimental poliomyelitis with incidental observations on certain manifestations in Macacus rhesus monkeys on a scorbutic diet. J Exp Med 69:507-515

33. Murphy BL, Krushak DH, Maynard JE, Bradley DW (1974) Ascorbic acid and its effects on parainfluenza type III virus infection in cotton-topped marmosets. Lab Anim Sci 24:229-232

34. Locke A, Locke RB, Bragdon RJ, Mellon RR (1937) Fitness, sulfanilamide and pneumococcus infection in the rabbit. Science 86:228-229

35. Messina L, Verga G (1937) L'azione dell'acido ascorbico sulla fagocitosi in vitro. Giorn Batteriol Immunol 19:850-855

36. Cattaneo C, Morellini M (1939) Reazioni immunitarie e sostanze riducenti. Boll Ist Sieroterap Milan 18:52-56

37. Busing KH (1939) Vitamin C als Heilmittel gegen Infektionen. München Med Wschr 86:575-579; 822-823

38. Cosentino G (1939) Acido ascorbico ed ormone cortico-surrenale nel trattamento locale di peritoniti acute sperimentali. Giorn Batteriol Immunol 23:531-550

39. Osborn TWB, Gear JHS (1940) Possible relation between ability to synthesize vitamin $C$ and reaction to tubercle bacillus. Nature 145:974

40. Pauling L (1970) Vitamin C and the common cold. Freeman, San Francisco [German translation: (1972) Vitamin C und der Schnupfen. Verlag Chemie, Weinheim]

41. Pauling L (1971) The significance of the evidence about ascorbic acid and the common cold. Proc Natl Acad Sci USA 68:2678-2681

42. Kleijnen J, Riet G, Knipschild PG (1989) Vitamine C en verkoudheid. Ned Tijdschr Geneeskd 133:1532-1535

43. Hemilä H (1997) Vitamin C intake and susceptibility to the common cold. Br J Nutr 77:59-72; 78:861-866

44. Hemilä H (1996) Vitamin C and common cold incidence: a review of studies with subjects under heavy physical stress. Int J Sports Med 17:379-383

45. Bessel-Lorck C (1959) Erkältungsprophylaxe bei Jugendlichen im Skilager. Med Welt (44):2126-2127

46. Baird IM, Hughes RE, Wilson HK, Davies JEW, Howard AN (1979) The effects of ascorbic acid and flavonoids on the occurrence of symptoms normally associated with the common cold. Am J Clin Nutr 32:1686-1690

47. Hemilä H (1997) Vitamin C supplementation and the common cold. Was Linus Pauling right or wrong? Int J Vitam Nutr Res 67:329-335

48. Hemilä H (1992) Vitamin C and the common cold. Br J Nutr 67:3-16

49. Hemilä H (1994) Does vitamin C alleviate the symptoms of the common cold? A review of current evidence. Scand J Infect Dis 26:1-6

50. Douglas RM, Chalker EB, Treacy B (1998) Vitamin C for the common cold. In: Acute respiratory infections module of The Cochrane Database of Systematic Reviews [updated 1 Dec 1997]. Available in The Cochrane Library [database on disk and 
CDROM]: The Cochrane Collaboration; Issue 1. Oxford: Update Software; (Updated quarterly)

51. Hemilä H (1998) Vitamin C supplementation and common cold symptoms. Factors affecting the magnitude of the benefit. Med Hypotheses (in press)

52. Karlowski TR, Chalmers TC, Frenkel LD, Kapikian AZ, Lewis TL, Lynch JM (1975) Ascorbic acid for the common cold. JAMA 231:1038-1042

53. Hemilä H (1996) Vitamin C, the placebo effect, and the common cold: a case study of how preconceptions influence the analysis of results. J Clin Epidemiol 49:10791084,1087

54. Asfora J (1977) Vitamin C in high doses in the treatment of the common cold. Int J Vitam Nutr Res [Suppl 16]:219-234

55. Szent-Györgyi A (1978) How new understandings about the biological function of ascorbic acid may profoundly affect our lives. Exec Health 14(8):1-4

56. Gander J, Niederberger W (1936) Vitamin C in der Pneumonie-Behandlung. Munchen Med Wochenschr 83:2074-2077

57. Hochwald A (1936) Beobachtungen über Ascorbinsaurewirkung bei der croupösen Pneumonie. Wien Arch Inn Med 29:353-374

58. Bohnholtzer E (1937) Beitrag zur Frage der Pneumoniebehandlung mit vitamin C. Dtsch Med Wochenschr 63:1001-1003

59. Hochwald A (1937) Vitamin C in der Behandlung der kruppösen Pneumonie. Dtsch Med Wochenschr 63:182-184

60. Posarelli S (1938) Sul trattamento delle polmoniti con la vitamina C. Policlinico (sez prat) 45:2138-2142

61. Ravetta M, Rettanni G (1938) Ricerche sulle proprieta terapeutiche della vitamina C. Gazz Ospedali Clin 69:771-786

62. Szirmai F (1940) Über den Wert des C-Vitamins in der Behandlung einzelner akuter Infektionskrankheiten. Dtsch Arch Klin Med 85:434-443

63. Klenner FR (1948) Virus pneumonia and its treatment with vitamin C. South Med Surg 110:36-38,46

64. Luberoff BJ (1978) Symptomectomy with vitamin C. A chat with Robert Cathcart. Chemtech 8:76-86

65. Cathcart RF (1981) Vitamin C, titrating to bowel tolerance, anascorbemia, and acute induced scurvy. Med Hypotheses 7:1359-1376

66. Hunt C, Chakravorty NK, Annan G, Habibzadeh N, Schorah CJ (1994) The clinical effects of vitamin $C$ supplementation in elderly hospitalised patients with acute respiratory infections. Int J Vitam Nutr Res 64:212-219

67. Glazebrook AJ, Thomson S (1942) The administration of vitamin C in a large institution and its effect on general health and resistance to infection. J Hygiene 42:1-19

68. Kimbarowski JA, Mokrow NJ (1967) Farbige Ausfallungsreaktion des Harns nach Kimbarowski, als Index der Wirkung von Ascorbinsaure bei Behandlung der Virusgrippe. Dtsch Gesundheitsw 22:2413-2418

69. Pitt HA, Costrini AM (1979) Vitamin C prophylaxis in marine recruits. JAMA 241:908-911

70. Hemilä H (1997) Vitamin C intake and susceptibility to pneumonia. Pediatr Infect Dis J 16:836-837

71. Pauling L (1986) How to live longer and feel better. Freeman, New York [German translation: (1990) Linus Pauling's Vitamin-Programm: Plädoyer für ein gesundes Leben. Bertelsmann, Munich]

72. Ritzel G (1961) Kritische Beurteilung des Vitamins C als Prophylacticum und Therapeuticum der Erkältungskrankheiten. Helv Med Acta 28:63-68 
73. Ritzel G (1976) Ascorbic acid and the common cold. JAMA 235:1108

74. Terezhalmy GT, Bottomley WK, Pelleu GB (1978) The use of water-soluble bioflavonoid-ascorbic acid complex in the treatment of recurrent herpes labialis. Oral Surg 45:56-62

75. Hasselbach F (1936) Vitamin C und Lungentuberkulose. Z Tuberk 75:336-347

76. Albrecht E (1938) Vitamin C als Adjuvans in der Therapie der Lungentuberkulose. Med Klin 34:972-973

77. Bauer G, Vorwerk W (1938) Beitrag zum Vitamin C-Defizit bei Lungentuberkulosen. Beitr Klin Tuberk 91:262-272

78. Hasselbach F (1938) Vitamine und Tuberkulose. Int J Vitam Nutr Res 7:152-173

79. Melzer E (1938) Über die Große des Vitamin C-Defizits und seine therapeutische Bedeutung bei Lungentuberkulose. Dtsch Tuberk B1 12:290-295

80. Pilz I (1938) Beeinflussung tuberkulös-exsudativer Schübe durch Vitamin C. Wien Med Wochenschr 88:1091-1093

81. Scartozzi C (1938) Rapporti tra vitamine e alcuni poteri immunitari. Vitamina C. Giorn Batteriol Immunol 21:902-932

82. Trautwein H (1938) Die Ascorbinsaure in der Behandlung der Lungentuberkulose. Beitr Klin Tuberk 91:411-421

83. Borsalino G (1937) La fragilita capillare nella tubercolosi polmonare e le sue modificazioni per azione della vitamin C. Giorn Clin Med 18:273-294

84. Warns EHJ (1938) De invloed van vitamine C op het beloop van been- en gewrichtstubercolose. Ned Tijdschr Geneesk 82:4426-4435

85. Baur H, Staub H (1954) Hepatitistherapie mit Ascorbinsäureinfusionen. Schweiz Med Wochenschr 84:595-597

86. Kirchmair H (1957) Die Hepatitis epidemica im Kindesalter und ihre Behandlung mit hohen Dosen Ascorbinsaure. Dtsch Gesundheitsw 12:1525-1536

87. Baetgen D (1961) Ergebnisse der Behandlung der Hepatitis epidemica im Kindesalter mit hohen Dosen Ascorbinsäure in den Jahren 1957/58. Med Monatsschr 15:30-36

88. Calleja HB, Brooks RH (1960) Acute hepatitis treated with high doses of vitamin C. Report of a case. Ohio Med J 56:821-823

89. Dalton WL (1962) Massive doses of vitamin C in the treatment of viral diseases. J Indiana Med Assoc 55:1151-1154

90. Banic S, Kosak M (1979) Prevention of posttransfusion hepatitis by vitamin C. Int J Vitam Nutr Res [Suppl 19]:41-44

91. Pauling L (1981) Vitamin C prophylaxis for posttransfusion hepatitis. Am J Clin Nutr 34:1978-1979

92. Patrone F, Dallegri F (1979) Vitamina C e sistema fagocitario: recenti acquisizioni e prospettive. Acta Vitaminol Enzymol 1:5-10

93. Rebora A, Crovato F, Dallegri F, Patrone F (1980) Repeated staphylococcal pyoderma in two siblings with defective neutrophil bacterial killing. Dermatologica 160:106-112

94. Rebora A, Dallegri F, Patrone F (1980) Neutrophil dysfunction and repeated infections. Br J Dermatol 102:49-56

95. Patrone F, Dallegri F, Bonvini E, Minervini F, Sacchetti C (1982) Effects of ascorbic acid on neutrophil function. Studies on normal and chronic granulomatous disease neutrophils. Acta Vitaminol Enzymol 4:163-168

96. Patrone F, Dallegri F, Bonvini E, Minervini F, Sacchetti C (1982) Disorders of neutrophil function in children with recurrent pyogenic infections. Med Microbiol Immunol 171:113-122 
97. Colombo ML, Girardo E, Incarbone E, Conti R, Ricci BM, Maina D (1989) Vitamina $\mathrm{C}$ in bambini affetti da trisomia 21. Minerva Pediatr 41:189-192

98. Levy R, Shriker O, Porath A, Riesenberg K, Schlaeffer F (1996) Vitamin C for the treatment of recurrent furunculosis in patients with impaired neutrophil functions. J Infect Dis 173:1502-1505

99. Pauling L (1977) Albert Szent-Györgyi and vitamin C. In: Kaminer B (ed) Search and discovery: a tribute to Albert Szent-Györgyi. Academic, New York, pp 43-54

100. Szent-Györgyi A (1934) Die medizinische Bedeutung des Vitamins C. Dtsch Med Wochenschr 60:556-557

101. Szent-Györgyi A (1934) Die medizinische und biologische Bedeutung des Vitamins C. Verh Dtsch Ges Inn Med (46th Congr):426-435

102. Szent-Györgyi A (1937) Neuere Ausblicke der Vitamintherapie. Dtsch Med Wochenschr 63:1789-1791

103. Szent-Györgyi A (1977) On a substance that can make us sick (if we do not eat it!). Exec Health 13(9):1-6

104. Chalmers TC (1975) Effects of ascorbic acid on the common cold. Am J Med 58:532-536

105. Dykes MHM, Meier P (1975) Ascorbic acid and the common cold. JAMA 231:1073-1079

106. Truswell AS (1986) Ascorbic acid. N Engl J Med 315:709 (minireview)

107. Hemilä H, Herman ZS (1995) Vitamin C and the common cold: a retrospective analysis of Chalmers' review. J Am Coll Nutr 14:116-123

108. Hemilä H (1996) Vitamin C supplementation and common cold symptoms: problems with inaccurate reviews. Nutrition 12:804-809

109. Chalmers TC (1996) Dissent to the preceding article by H. Hemilä. J Clin Epidemiol 49:1085

110. Liberati A (1996) Thomas C Chalmers. Lancet 347:188

111. Hemilä H (1986) A re-evaluation of nutritional goals - not just deficiency counts. Med Hypotheses 20:17-27

112. Herbert V (1993) Does mega-C do more good than harm, or more harm than good? Nutr Today 28(1):28-32

113. Newmark HL, Scheiner JM, Marcus M, Prabhudesai M (1979) Ascorbic acid and vitamin B12. JAMA 242:2319-2320

114. Marcus M (1981) Vitamin $\mathrm{Bi}_{2}$ : response to Dr. Herbert. Am J Clin Nutr 34:1622-1624

115. Hemilä H (1994) The good and harm of vitamin C. Nutr Today 29(2):49-50

116. Hanck A (1982) Tolerance and effects of high doses of ascorbic acid. Int J Vitam Nutr Res [Suppl 23]:221-238

117. Bendich A, Langseth L (1995) The health effects of vitamin C supplementation. J Am Coll Nutr 14:124-136 and 398

118. Marinacci B (1995) Linus Pauling in his own words. Simon and Schuster, New York, pp 249-251

119. Knipschild P (1994) Systematic reviews. Some examples. BMJ 309:719-721 


\section{Table of Contents}

Antioxidants and Human Health

H.SIES, W.STAHL

Modulation of Cell Death by Oxidants and Antioxidants.

Metabolism and Metabolic Interactions of Vitamin C

T. BYERS, J. MOUCHAWAR

Vitamin $\mathrm{C}$ and Gastric Cancer Prevention

Recommended Vitamin C Intake:

From Molecular Mechanisms to Clinical Application 


\section{R. Paoletti $\bullet$ H. Sies \\ J. Bug • E. Grossi • A. Poli \\ (Eds)}

\section{Vitamin C}

The state of the art in disease prevention sixty years after the Nobel Prize

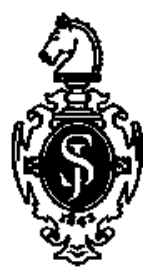

Springer 
RODOLFOPAOLETTI

Institute of Pharmacological Sciences

Faculty of Pharmacy

University of Milan (Italy)

HELMUT SIES

Institute of Physiological Chemistry

University of Dusseldorf (Germany)

JOACHIM BUG

Merck Pharma, Self-Medication International

Merck KGaA

Darmstadt (Germany)

ENZO GROSSI

Ethical Drugs Medical Department

Bracco Spa

Milan (Italy)

ANDREA POLI

Nutrition Foundation of Italy

Milano

(C) Springer-Verlag Italia, Milano 1998

\section{ISBN 88-470-0027-0}

Library of Congress Cataloging-in-Publication Data: Vitamin C : the state of the art in disease prevention sixty years after the Nobel Prize / [edited by] R. Paoletti ... [et al.]. p. cm. Includes bibliographical references and index. ISBN 8847000270 1. Vitamin C-Physiological effect. 2. Vitamin C-Therapeutic use. 3. Chemoprevention. I. Paoletti, Rodolfo. [DNLM: 1. Ascorbic Acid-pharmacology. 2. Ascorbic Acid--therapeutic use. 3. Primary Prevention. QU 210 V8372 1998] QP772.A8V574 1998 615'.328-DC21 DNLM/DLC for Library of Congress 98-24805 CIP

This work is subject to copyright. All rights are reserved, whether the whole or part of the material is concerned, specifically the rights of translation, reprinting, re-use of illustrations, recitation, broadcasting, reproduction on microfilms or in other ways, and storage in data banks. Duplication of this publication or parts thereof is only permitted under the provisions of the Italian Copyright Law in its current version and permission for use must always be obtained from Springer-Verlag. Violations are liable for prosecution under the Italian Copyright Law.

The use of general descriptive names, registered names, trademarks, etc., in this publication does not imply, even in the absence of a specific statement, that such names are exempt from the relevant protective laws and regulations and therefore free for general use.

Product liability: the publishers cannot guarantee the accuracy of any information about dosage and application contained in this book. In every individual case the user must check such information by consulting the relevant literature.

Cover design: Simona Colombo, Milan Typesetting and layout: Graphostudio, Milan Printing and binding:

Staroffset, Cernusco S.N. (Milan)

SPIN: 10677443 